\title{
Energy and Economic Development in Nigeria: An Econometric Approach based on Fractional Integration
}

\author{
Samuel Chibuzor Umeh ${ }^{1} \&$ Luis A. Gil-Alana ${ }^{1,2}$ \\ ${ }^{1}$ School of Economics, University of Navarra, Pamplona, Spain \\ ${ }^{2}$ University Francisco de Vitoria, Madrid, Spain \\ Correspondence: Prof. Luis A. Gil-Alana, University of Navarra, School of Economics, Edificio Amigos, 31009 \\ Pamplona, Navarra, Spain. Tel: 3- 948-425-625
}

Received: April 14, 2021 Accepted: April 23, 2021 Online Published: May 28, 2021

The research is financed by the MINEIC-AEI-FEDER ECO2017-85503-R project from 'Ministerio de Economia, Industria y Competitividad' (MINEIC), 'Agencia Estatal de Investigación' (AEI) Spain and 'Fondo Europeo de Desarrollo Regional' (FEDER). An internal Project from the Universidad Francisco de Vitoria is also acknowledged.

\begin{abstract}
The relationship between economic development and energy in Nigeria is examined in this work. An econometric model is developed to ccount for the factors affecting economic growth and development in the country. The results show that the variables have long memory and all except electricity consumption are non-mean reverting. The series are heterogeneous with respect to the order of integration. Using OLS regressions with fractionally integrated errors, we found that electricity consumption, oil prices, electricity prices, real interest rate and employment affect GDP per capita with only real interest rate having a negative relationship. Policy recommendations are proposed in the article.
\end{abstract}

Keywords: energy, economic development, long-range dependence, fractional differentiation, fractional cointegration

\section{Introduction}

The argument on the importance of energy in development economics is still a thing of contention. Empirical works have churn out varying results: some have supported the view that energy complements other factors of production, while others have argued against this assertion by supporting that energy can substitute for other production factors.

The need to investigate the relation between economic growth and energy comes from the increasing of energy for the economic development of nations. This might question the neoclassical production function where labour, land and capital are recognized as the main production factors. The analysis has been extended in recent years to include energy (Ebohon, 1996). Taking the relationship between energy and capital as a factor of production for example, there is no congruent agreement on the relation between capital and energy; rather a conflict of findings is reported. Hudson and Jorgenson (1974), Berndt and Wood (1975) and Matsui et al. (1978) (see, also Susuki and Takenaka, 1981) found capital and energy be complementary. On the other hand, authors such as Griffin (1979) found energy and capital to be substitutable.

Energy is the main factor in the economic growth and development of Nigeria. It plays an important role in the international diplomacy of the country and it is a tradable commodity for national income earnings, which is utilized in supporting government development programmes. It also substitutes as an input into the production of goods and services in the nation's industry, transport, agriculture, health and education sectors, as well as a vital instrument for politics, diplomacy and security (Sambo, 2009).

The energy sector in Nigeria has contributed more than $70 \%$ of Nigeria's Federal revenue. The national development programmes and security of Nigeria largely depend on these revenues. The energy sector, especially oil has over the past five years contributed on the average, close to $25 \%$ to Nigeria's GDP, which is the highest contributor after crop production. The contribution of energy sector to Nigerian GDP is expected to be higher when we consider utilization of renewable energy, which constitutes about $90 \%$ of the energy used in rural population. 
Nigeria is immensely blessed with primary energy resources. The country is the world's tenth largest reserves of crude oil currently estimated to be about 36 billion barrels (about 4.896 billion tonne of oil equivalent (toe)) in 2006. Nigeria is also more of a natural gas island than oil with an estimated endowment of about 166 trillion standard cubic feet (5210 billion $\mathrm{m} 3$ ) in 2006. This includes associated and non-associated reserves, placing Nigeria as one of the top 10 countries with the largest gas reserves in the world (NNPC, 1997; Oyedepo, 2012).

Other important energy resources in Nigeria include: Tar sands $-\sim 31$ billion barrels oil equivalent (4.216 billion toe); lignite and coal - estimated to be $\sim 2.7$ billion tonnes (1.882 billion toe); Large Hydropower Potentials $\sim 10,000 \mathrm{MW}$; Small Hydropower Potentials, provisionally estimated to be $\sim 734 \mathrm{MW}$.

Nigeria has faced with energy crises. The striking energy problems in Nigeria are oil price volatility, electricity supply shortages and environmental degradation because of oil mining activities. Despite Nigeria's humongous endowment of energy resources, she is still faced with persistent electricity shortages, which stems from financial, structural and socio-political causes. In comparison with other developing countries of the world, the Nigerian power sector has performed abysmally low.

Oil price volatility continues to have an impact on the growth rate in Nigeria. Between 2000 and 2014, GDP in Nigeria grew at an average yearly rate of 7\%. Following the oil price collapse in 2014-2016, combined with negative production shocks, GDP growth rate dropped to $2.7 \%$ in 2015. According to the World Bank (2019), in 2016 during its first recession in 25 years, the economy contracted by $1.6 \%$.

Another energy issue in Nigeria is that of oil spillage causing environmental degradation. Oil spillage can be defined as the illegal, unwanted, or unlawful release of liquid petroleum hydrocarbons within the environment, owing to accident and or intentional human factors; hence, this is known as oil pollution.

Oil spillage occurs in different forms, and it is attributed to various factors such as equipment failures and human error (leakages/spills during processing and at refining plants, drilling rigs and from oil wells, rusting / corrosion of oil piping and installations, improper maintenance of infrastructures, the release of crude oils from offshore platforms) as well as continued menace of deliberate sabotage/damaging pipelines and the theft of crude oils by vandals which cost the Nigerian nation billions of dollars (Amnesty International, 2011 and NNPC, 2013) (Saleh et al., 2017).

The Department of Petroleum Resources estimated 1.89 million barrels of petroleum were spilled into the Niger Delta during the years 1976 -1996 out of a total of 2.4 million barrels spilled in 4,835 incidents (see, e.g., Vidal, 2010 and Daily Independent, 2010).

A report by (UNDP 2013, p.76) indicates that there has been a total of 6,817 oil spills for the period 1976 - 2001 , which account for a loss of three million barrels of oil, of which more than $70 \%$ was not recovered. $69 \%$ of these spills occurred offshore, a quarter was in swamps and $6 \%$ spilled on land.

The risk and uncertainty associated to this is numerous, one of which is that, the oil has the ability to remain at the lower level of the water (river, sea or ocean) for many years to come, which leads to a harmful and deadly effects to the aquatic lives living within and at the floor of the aquatic habitat. Similarly, the cleansing process of such aquatic habitat becomes extremely complicated and difficult, especially if such pollution is observed to occur in large amounts, volumes and or quantities. Also, any resultant measure taken to correct such pollution, will be at the expense of many existing futile, if and only if, effective sustainable measures are not taken at the earliest time possible. However, environmental sustainability requires effective awareness and preventive measures instead of mitigation processes. (Alaska, 2004; Saleh, 2015; U.S. Fish \& Wildlife, 2017; etc.).

\subsection{Research Problem}

As stated earlier, Nigeria is blessed greatly with energy resources both renewable and non-renewable energy resources. Despite these, Nigeria is faced with development problems. Literature on other developing and developed nations have shown that energy sectors contribute significantly to the economic growth and development. Thus, this research tends to find out the energy experience of the Nigerian state and how it relates to her economic development.

\subsection{Research Hypothesis}

(a) $\mathrm{H}_{0}$ : The individual series are not long memory.

(b) $\mathrm{H}_{0}$ : The individual series are non-stationary.

(c) $\mathrm{H}_{0}$ : The individual series are non-mean reverting.

(d) $\mathrm{H}_{0}$ : There is no long run equilibrium relationship amongst the variables. 
(e) $\mathrm{H}_{0}$ : The independent variables do not affect GDP per capita.

\subsection{Justification of Study}

The African Development Bank launched a project tagged 'Light Up and Power Africa - A New Deal on Energy' due to the realization that energy access for all is one of the enhancers of inclusive growth as it creates opportunities for women, youths, and children both in urban and rural areas, attainment of health and education outcomes, decreasing the cost of doing business and for unlocking economic potential and jobs creation. Therefore, research on how energy affects economic development in Nigeria, an African nation is justifiable.

\subsection{Significance of Study}

The findings in this study will be useful for energy policy planners and analysts in Nigeria in planning for the development and conservation of energy in the country.

It will also be useful to economic planners in Nigeria in drawing useful short and long-term economic development plans (taking energy into great consideration). Finally, it will also be useful to researchers who want to be abreast with the long run relationship between energy and economic development in emerging markets and developing economies, (of which Nigeria belongs to) as this is a field of research not much investigated in economics.

\section{Literature Review}

\subsection{Theoretical Review}

Firstly, we look at theories that explains the energy-economic growth/development nexus. The resource curse was first presented by economic geographer Richard Auty (Auty, 1993), also termed as the paradox of plenty; it is an important theory that helps explain the relationship between energy and economic development. It refers to the paradox that countries with an abundance of natural resources tend to have lesser economic growth, lesser democracy, and far negative development outcomes in comparison with countries with fewer natural resources. This have attracted theories and much academic debate about the reasons for, and exceptions to, these negative outcomes. Majority of experts have the belief that the resource curse does not apply to the whole nations/places/economies of the world or inevitable, but that it affects certain countries under some specific conditions (Ross, 2015; Venables, 2016).

Another theory, which can help in explaining the energy-economic growth/development nexus, is the Dutch disease theory. The theory talks about the negative effect of sudden increase in the value of a nation's currency due to the discovery of valuable natural resource and the unexpected reactions that such a discovery can have on the overall economy of a nation. According to Gylfason (2001), 'Dutch disease' refers to the fears of deindustrialization that gripped the Netherlands as a consequence of the spike in the value of the Dutch guilder due to the discovery of natural gas deposits in the country in the North Sea during the late 50s and early 60s. Therefore, it was reasoned that the appreciation of the currency that followed the gas export boom reduced the profitability of manufacturing and service exports.

\subsection{Empirical Review}

Ebohon (1996) found out a simultaneous causal relation between energy and economic growth for both Nigeria and Tanzania, which implies that without easing the constraints to energy supply, economic growth and development will remain elusive to these countries.

A large body of empirical works from the recent past two decades confirms the presence of a strong historical link between economic growth and energy consumption, with most empirical results indicating that economic growth can indeed cause increases in energy consumption (Glasure, 2002; Ghali and El-Sakka, 2004; Akinlo, 2008; Apergis and Payne, 2009). Yoo (2006) found a bi-directional causal relationship between oil consumption and economic growth in Korea. Lee and Chang (2007) found for the Taiwanese case, a positive relationship between energy consumption and economic growth. Narayan and Smyth (2007), Chen and Lee (2007) and Hsu et al. (2008) and Mishra et al. (2009) researched on the stationarity of aggregate energy consumption using panels of countries and employing unit root methods. These studies found non-stationarity in the series and are in line with the findings of Lean and Song (2009) which studied the long-range dependence in the U.S. petroleum consumption by sector.

Acaravci and Ozturk (2010) discovered a long-run relationship between carbon emissions per capita, energy consumption per capita, real gross domestic product (GDP) per capita and the square of per capita real GDP only for Denmark, Germany, Greece, Iceland, Italy, Portugal, and Switzerland. They also found out that there exists, a positive long-run elasticity estimates of emissions with respect to energy consumption in Denmark, Germany, Greece, Italy, and Portugal. Positive long-run elasticity estimates of carbon emissions with respect to real GDP and the negative long-run elasticity estimates of carbon emissions with respect to the square of per capita real GDP 
at $1 \%$ significance level in Denmark and at 5\% significant level in Italy are also found. The results strengthen the validity of environmental Kuznets curve (EKC) hypothesis in Denmark and Italy. These results point to the fact that energy conservation policies, such as rationing energy consumption and controlling carbon dioxide emissions, are likely to have no adverse effects on the real output growth and EKC hypothesis is not valid for the most countries considered in this study. Bownden and Payne (2010) found a causal relationship from non-renewable industrial energy consumption to GDP growth in the US. Ghosh (2010) shows no long-run equilibrium relationship and long-term causality between carbon emissions and economic growth in India though there exists a bidirectional short-run causality between the two. It shows a unidirectional short-run causality from economic growth to energy supply and energy supply to carbon emissions.

Dealing with Sub Saharan Africa, Kebede et al. (2010) found an inverse relationship between energy consumption and industrial development, but a positive relation with GDP. Warr and Ayres (2010) found a causal relation from energy consumption to economic growth in the US. Therefore, to maintain growth in the long-run, it is needful to increase either energy suppliers or energy use efficiency. According to Payne (2010), there exists a uni-directional causal relation from biomass energy consumption to economic growth in USA. Fallahi (2011), on the other hand, found a strong bi-directional causal relation between energy consumption and GDP growth in the US. You (2011) found a strong relationship between renewable energy consumption and sustainable development in China through a multiplier effect on the savings and economic growth; however, the increase in fossil fuel energy consumption increases China's economic growth only. Al-mulali and Che Sab (2012) found out that energy consumption has a positive relationship with both financial development and economic growth in Sub-Saharan African countries, but with an attendant high pollution. Corina and Claudiu (2012) in a comparative study for Romania, Spain and the European Union as regards energy-economic growth nexus found out a long run relationship between energy consumption and economic growth (GDP per capita) for both states and the EU. They also found a short run relation from renewable energy consumption to economic growth in Romania, and for Spain between energy growth and natural gas. Oyedepo (2012) established that energy efficiency and renewable energy are two factors that unites to achieve sustainable development and climate change mitigation in Nigeria. Oyedepo (2014) concludes that affordable and reliant energy that is readily available is a pre-condition for sustainable development.

Cho et al. (2015) reveal the existence of uni-directional relationship between GDP and renewable energy for 31 OECD countries in their study. Mazur et al (2015) reveal no strong evidence that income is negatively correlated with carbon dioxide emission levels. Can and Gozgor (2017) give support to the validity of the EKC hypothesis in France, reveal that energy consumption has a positive effect on $\mathrm{CO}_{2}$ emissions, and that a higher economic complexity suppresses the level of $\mathrm{CO}_{2}$ emissions in the long run. Gil-Alana et al. (2017) carried out a long memory study of several Kenyan electricity prices series and discovered that they are nonstationary, containing unit roots, and implying permanent shocks lasting forever. In this current research on Energy-Economic development in Nigeria, we employ fractional integration and cointegration techniques to determine if signs of persistence or reversion to the mean can be discovered with the energy and other (economic)-related variables under study. Rafindadi and Ozturk (2017) in their study reveal increase in renewable energy consumption leads to an increase the income in Germany. Dong et al. (2018) studied the nexus among income- $\mathrm{CO}_{2}$ emissions-renewable energy for 128 countries in six subgroups of regions. The study shows for Europe and Eurasia countries, a bi-directional causal relationship between economic growth and carbon emissions as well as a uni-directional causality from renewable energy to $\mathrm{CO}_{2}$ emissions. Soava et al. (2018) show that renewable energy consumption positively impacts on economic growth, and stress the existence of bi-directional or uni-directional Granger causalities between the two macroeconomic indicators, for each country in the panel of European Union countries studied. Wesseh and Lin (2018) show a bi-directional relationship between all energy types and economic growth in Egypt. Akinsola and Odhiambo (2020), in examining the impact of oil price on economic growth in seven low-income oil-importing sub-Saharan African (SSA) countries, namely Ethiopia, Gambia, Mali, Mozambique, Senegal, Tanzania and Uganda using panel-ARDL, reveal that oil price does not have a significant impact on economic growth in the short run for the group, but has a negative significant impact in the long run, though oil price has a significant but mixed effect on economic growth in all the seven countries in the short-run. Using NARDL Model in examining the asymmetric effect of oil price on economic growth by decomposing oil price into negative and positive changes, they found out that a decrease in oil price has a positive and significant impact on economic growth, while oil price increase has a significant negative effect. Radmehr, Henneberry and Shayanmehr (2021) observed positive spatial correlations linkages among economic growth, carbon emissions, and renewable energy consumption for European Union (EU) countries, and that economic growth is stronger spatially correlated than carbon dioxide $\left(\mathrm{CO}_{2}\right)$ emissions or renewable energy consumption. Their results confirm a bi-directional relationship between economic growth and carbon emissions, and between economic growth and renewable energy consumption, and a uni-directional nexus between economic growth and renewable energy consumption. 


\section{Historical Context of GDP Per Capita in Nigeria}

Nigeria, a middle-income country has a mixed economy with emerging market and growing manufacturing, financial and service sectors. It is ranked as the 30th-largest economy in the world in terms of nominal GDP, it is also the 23rd-largest in terms of purchasing power parity (World Bank, 2014).

Despite massively hindered by years of thoughtless financial mismanagement and misappropriation, the GDP at purchasing power parity (PPP) of Nigerian tripled to $\$ 451$ billion in 2012 from $\$ 170$ billion in 2000. It is an oilbased economy ranked $129^{\text {th }}$ in the world and $17^{\text {th }}$ in Africa with respect to GDP (PPP) per capita.

From the inception of Nigeria's independence in 1960, the average Nigerian growth rate GDP per capita has been 1.7 percent per year. According to Akinkunmi, (2017), the average real GDP per capita hovered around US\$1222 between the years $1950-1959$.

This amount moved higher to US $\$ 1477$ under the regime of Nigeria's first president. Nigeria's post-independence experience was featured by a relative fall after a period of relatively steady growth that lasted until 1974 . However, the stable economic performance of the $60 \mathrm{~s}$ and early $70 \mathrm{~s}$ was not maintained in the decades after. (See Figure 1 below).

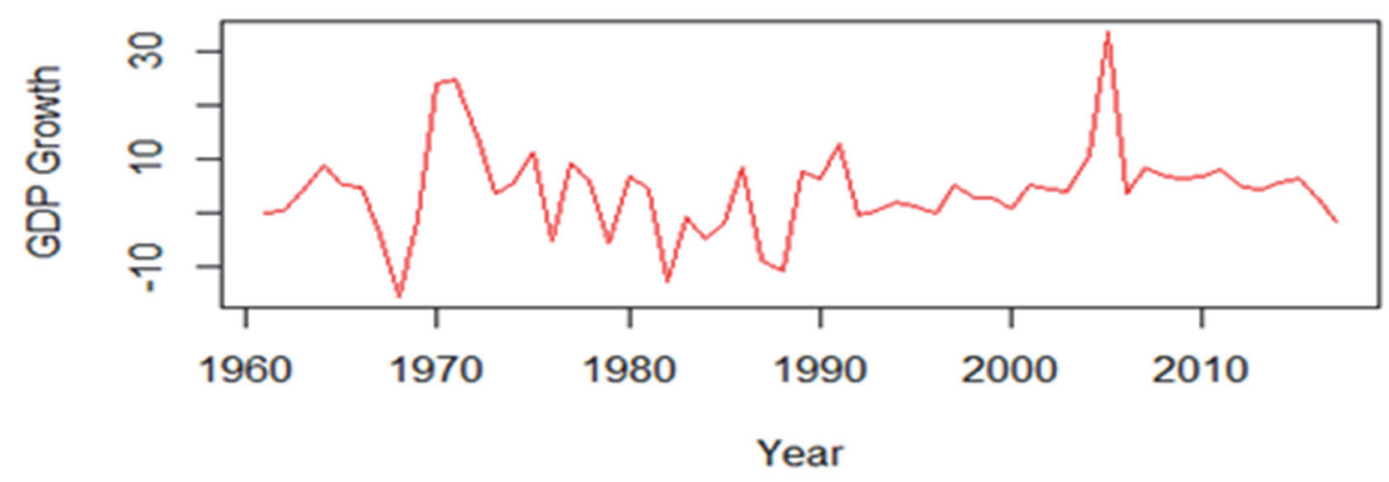

Figure 1. GDP growth in Nigeria (Awe, Mudida and Gil-Alana, 2020)

The GDP per capita reached a peak of about US\$1804 on average during the military period of President Olusegun Obasanjo (1970 - 1979). After the Obasanjo's military regime, a decreasing trend of average real GDP per capita was observed. Before the adoption of the Structural Adjustment Programme (SAP) in 1986, the average per capita was around US\$ 1544 between 1960 and 1985. Nevertheless, a fall in real GDP per capita was experienced after the SAP era.

The real GDP per capita on average was US\$1446 when the country was under the military regime. Since the embrace of a democratic system in the country, there was an improvement in the real GDP per capita. It is shown in Figure 1 that the highest annual growth rate of GDP per capita was observed in the period between 2003 and 2007, while the least growth rate in the country was linked to the period before democracy (Akinkunmi, 2017; Awe, et al, 2015,).

In addition, the growth rate of GDP per capita in the post-SAP era was greater compared to the pre-SAP era. Under the military administration of President Gowon, Nigeria experienced the highest growth rate of economic growth but its real GDP per capita had the highest during the military administration of Olusegun Obasanjo. The drastic decline in the per capita GDP growth rate of Nigeria was noticeable when President Shehu Shagari took over the affairs of the country (Awe et al., 2018).

It is evident that the discovery of oil in Nigeria contributed to the current level of economic performance. Therefore, there is a high demand for an evidence-based answer on the impact of the energy sector on economic development in Nigeria vis-à-vis GDP per capita. This justifies the relevance of the present study in providing useful insights to the energy-economic development nexus in Nigeria. According to Awe et al. (2018), the performance of the Nigerian economy had improved since 2009; however, it is still characterized by low savings accompanied by poor economic diversification. 


\section{Methodology}

We use methods based on the concept of fractional integration that means that the number of differences required in the series to render it stationary I(0) might be a fractional number. In other words, a time series is said to be I(d) or integrated of order $\mathrm{d}$ if it can be presented as:

$$
(1-L)^{d} x_{t}=u_{t}, \quad t=1,2, \ldots,
$$

where $\mathrm{L}$ is the lag operataor, $\mathrm{x}_{\mathrm{t}}$ is supposed to be $\mathrm{I}(0)$ or integrated of order 0 , that means that the infinite sum of its autocovariance is finite, or alternatively, in the frequency domain, that the spectral density function is positive and finite at all frequencies. In the empirical work carried out in the following section, we consider a regression of the following form:

$$
y_{t}=f\left(\theta ; z_{t}\right)+x_{t}, \quad t=1,2, \ldots,
$$

where $\mathrm{y}_{\mathrm{t}}$ is the GDP in Nigeria, $\mathrm{f}$ is a linear function, $\mathrm{z}_{\mathrm{t}}$ is a vector of regressors that may include deterministic terms like a constant and a time trend, or exogenous regressors, and $x_{t}$ is given by (1). The estimation is based on the Whittle function expressed in the frequency domain as proposed in Robinson (1994).

\section{Data and Empirical Results}

\subsection{Dataset and Data Sources}

We use data referring to the following variables, with definitions and sources provided in Table 1: GDP per capita, oil export, electricity (electric power) consumption, oil price, electricity price, real interest rate, real effective exchange rate and employment. The sample period examined for the multivariate analysis was from 1991 to 2018 and same for the univariate analysis and time series plots for all variables except employment which started from 1981 to 2018. At the time of the study, there was no data for 2019 and 2020. The frequency for all variable is annual. GDP per capital was sourced from World Bank National Accounts data, and OECD National Accounts data files. Oil exports was sourced from Statistical bulletin of National Bureau of Statistics and Central Bank of Nigeria. Data for electricity (electric power) consumption was obtained from World Bank Development Indicators. That of oil prices and electricity prices was from BP Statistical Review of World Energy June, 2019 and Nigeria Electricity Regulatory Commission MYTO, 2019 respectively. For the electicity prices (tariffs) in Nigeria, there are different types of electricity prices (tariffs), namely; industrial, residential, commercial, street light and special tarrif class. This study used industrial electricity prices. Data for real effective exchange rate and real interest rate were obtined from World Bank development indicators at IMF, International Financial Statistics. Finally, data for employment came from Federal Reserve Economic Data, Federal Reserve Bank of St. Louis (FRED).

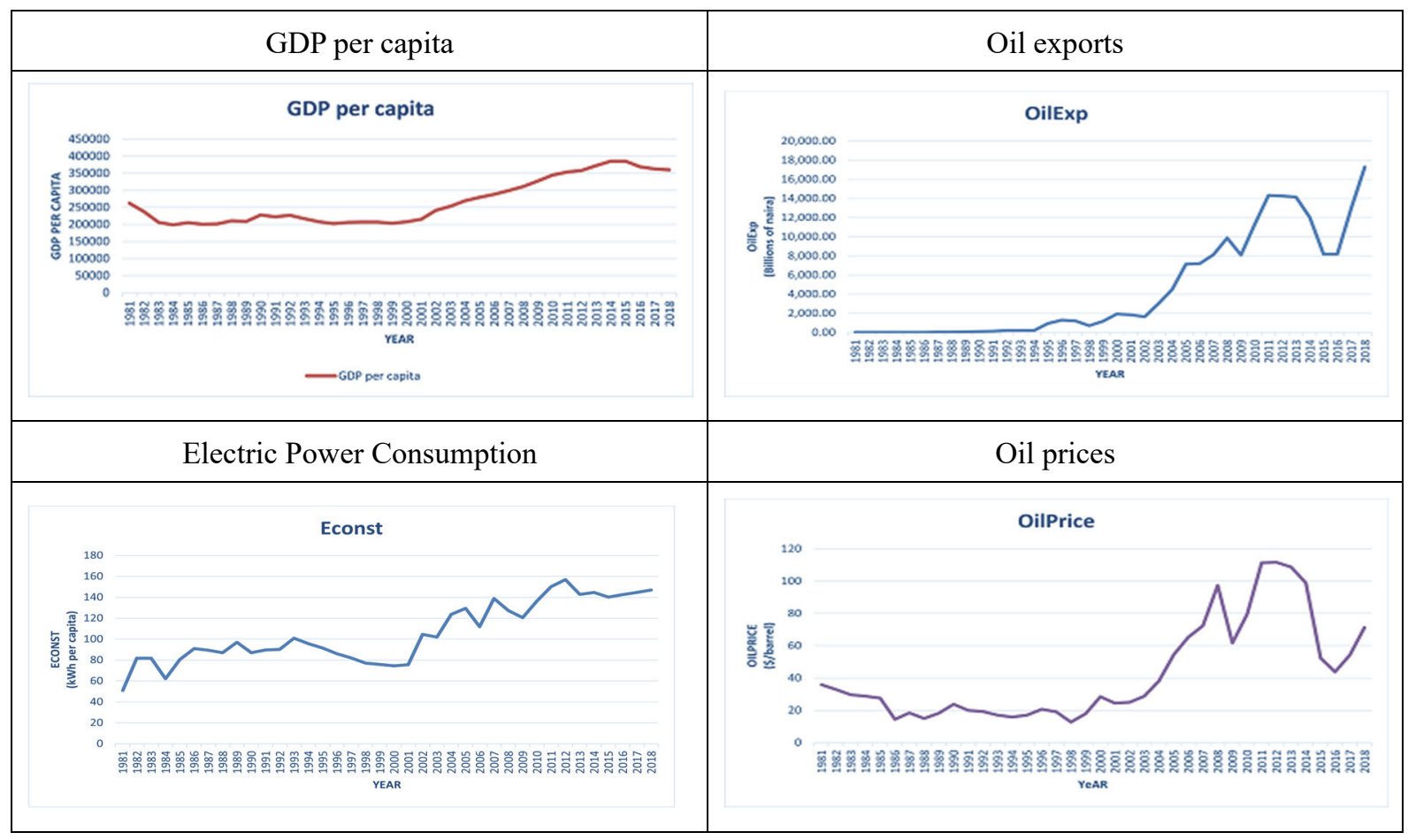




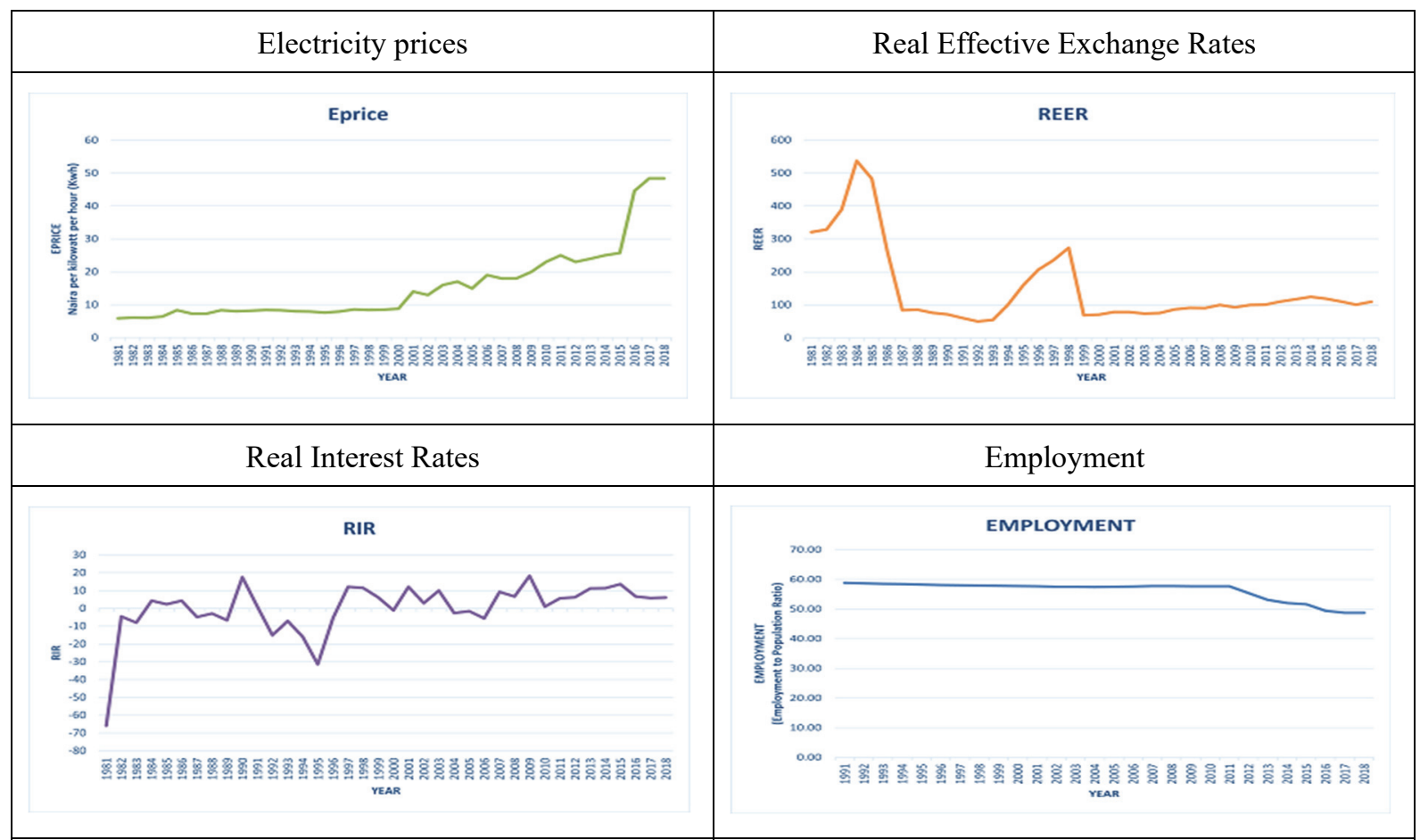

Figure 1. Time series plots

Table 1. Data variables

\begin{tabular}{|c|c|}
\hline Indicator Name & Long definition \\
\hline $\begin{array}{l}\text { GDP per capita } \\
\text { (constant LCU) } \\
\text { (GDP PC) }\end{array}$ & $\begin{array}{l}\text { GDP per capita is GDP divided by midyear population. } \\
\text { GDP at purchaser's prices is the sum of gross value added by } \\
\text { all resident producers in the economy plus any product taxes } \\
\text { and minus any subsidies not included in the value of the } \\
\text { products. It is calculated without making deductions for } \\
\text { depreciation of fabricated assets or for depletion and } \\
\text { degradation of natural resources. Data are in constant local } \\
\text { currency. }\end{array}$ \\
\hline
\end{tabular}

Oil export

(OILEXP)

Electric power consumption $(\mathrm{kWh}$ per capita) (EPC)

Oil price (\$/barrel)

Electricity Price

(EPRICE)

Real effective exchange rate index $(2010=100)$

(REER/ERER)

Real interest rate $(\%)$
Oil export measured in Billions of naira

(Nigerian local currency)

Electric power consumption measures the production of power plants and combined heat and power plants less transmission, distribution, and transformation losses and own use by heat and power plants.

Price of a barrel of crude oil in dollars

Price of electricity measured in Naira per kilowatt per hour (Kwh). Industrial electricity prices (tariffs) were used in this research.

Real effective exchange rate is the nominal effective exchange rate (a measure of the value of a currency against a weighted average of several foreign currencies) divided by a price deflator or index of costs.

Real interest rate is the lending interest rate adjusted for inflation as measured by the GDP deflator. The terms and
Source

World Bank national accounts data, and OECD National Accounts data files.

National Bureau of Statistics and Central Bank of Nigeria

World Bank

Development

Indicators

BP Statistic, 2019

Nigeria Electricity Regulatory

Commission MYTO, 2019.

WB,

World

Bank

development

indicators gotten from

IMF, International

Financial Statistics.

WB development indicators gotten from 


\begin{tabular}{lll} 
(RIR) & $\begin{array}{l}\text { conditions attached to lending rates differ by country, } \\
\text { however, limiting their comparability. }\end{array}$ & $\begin{array}{l}\text { IMF, International } \\
\text { Financial Statistics and } \\
\text { data files using World } \\
\text { Bank data on the GDP } \\
\text { deflator. }\end{array}$ \\
& Employment to Population Ratio for Nigeria, Percent, Annual, & $\begin{array}{l}\text { FRED, Federal } \\
\text { Reserve Economic } \\
\text { Employ }\end{array}$ \\
(EMPLOYMENT) & Not Seasonally Adjusted & $\begin{array}{l}\text { Data, Federal Reserve } \\
\text { Bank of St. Louis }\end{array}$ \\
\hline (EMP) &
\end{tabular}

\subsection{Univariate Results}

We start by presenting the results of the univariate series and look first at its statistical properties by looking at the degree of differentiation of the series. Following the standard parameterization of I(1) or unit root processes, we include a constant and a linear time trend, and consider the model,

$$
y_{t}=\alpha+\beta t+x_{t}, \quad(1-L)^{d} x_{t}=u_{t}, \quad t=1,2, \ldots,
$$

where $y_{t}$ is the series we observe, $\alpha$ and $\beta$ are unknown coefficients referring respectively to a constant and a linear trend, and the errors in the first equation in $(1), \mathrm{x}_{\mathrm{t}}$, are $\mathrm{I}(\mathrm{d})$, so that $\mathrm{u}_{\mathrm{t}}$ is a white noise process.

Table 2. Estimates of $d$ in equation (3)

\begin{tabular}{llllllllll}
\hline Series & \multicolumn{3}{l}{ No terms } & \multicolumn{3}{l}{ A constant } & \multicolumn{3}{c}{$\begin{array}{l}\text { A constant and a linear } \\
\text { trend }\end{array}$} \\
\hline GDP PC & 0.88 & $(0.66$, & $1.20)$ & $\mathbf{1 . 4 7}$ & $\mathbf{( 1 . 2 5}, \mathbf{1 . 7 8})$ & 1.45 & $(1.25$, & $1.72)$ \\
OILEXP & 0.62 & $(0.51$, & $1.10)$ & 0.92 & $(0.77$, & $1.20)$ & $\mathbf{0 . 9 0}$ & $\mathbf{( 0 . 7 2 ,}$ & $\mathbf{1 . 1 8})$ \\
EPC & 0.97 & $(0.74$, & $1.31)$ & 0.52 & $(0.40$, & $0.87)$ & $\mathbf{0 . 5 2}$ & $\mathbf{( 0 . 2 7 ,} \mathbf{0 . 9 6})$ \\
OILPRICE & 0.84 & $(0.53$, & $1.26)$ & $\mathbf{0 . 9 4}$ & $\mathbf{( 0 . 7 6 ,}$ & $\mathbf{1 . 2 4})$ & 0.94 & $(0.74$, & $1.24)$ \\
EPRICE & 0.89 & $(0.70$, & $1.16)$ & 0.81 & $(0.68$, & $1.02)$ & $\mathbf{0 . 7 7}$ & $\mathbf{( 0 . 5 8 ,}$ & $\mathbf{1 . 0 3})$ \\
ERER & 0.94 & $(0.70$, & $1.28)$ & $\mathbf{1 . 0 8}$ & $\mathbf{( 0 . 7 3 ,}$ & $\mathbf{1 . 5 6})$ & 1.08 & $(0.77$, & $1.57)$ \\
RIR & 0.11 & $(-0.10$, & $0.44)$ & 0.11 & $(-0.11$, & $0.43)$ & $\mathbf{0 . 0 7}$ & $\mathbf{( - 0 . 2 9 ,}$ & $\mathbf{1 . 0 7})$ \\
EMPLOYMENT & 0.86 & $(0.58$, & $1.24)$ & $\mathbf{1 . 3 7}$ & $\mathbf{( 1 . 1 6 ,}$ & $\mathbf{1 . 8 5})$ & 1.40 & $(1.19$, & $1.93)$ \\
\hline
\end{tabular}

In parenthesis, the $95 \%$ confidence intervals; in bold, the significant models according to the deterministic terms.

Table 2 presents the estimates of $d$ and the $95 \%$ bands of the non-rejection values of $d$ using Robinson (1994) in equation (3) under three different modelling specifications for the deterministic terms. Thus, in the second column, we present the results supposing that $\alpha=\beta=0$ a priori, so no deterministic components are included in the model; in the third column, we report the estimated values of $d$ under the assumption that $\alpha$ is unknown and $\beta=0$ a priori, i.e., including an intercept in the regression model; finally, in the last column, we estimate $\mathrm{d}$ along with $\alpha$ and $\beta$ also estimated from the data. We display in the table in bold the most adequate model for each series. This is based on the corresponding $\mathrm{t}$-values on the estimated coefficients in the d-differenced regression.

We observe that the time trend is significant for OILEXP, EPC, EPRICE and RIR, while an intercept seems to be sufficient in the remaining of the cases. Focusing on the values of $d$ we notice that $d$ is significantly higher than 1 for GDP PC and EMPLOYMENT; the unit root hypothesis, i.e., $d=1$ cannot statistically be rejected for OILEXP, OILPRICE, EPRICE, ERER, and for RIR, the interval is so wide that both I(0) and I(1) hypotheses cannot be rejected. Thus, the results are very heterogeneous depending on the series examined ranging from low levels of persistence (RIR) to a very high level as in GDP PC.

The use of alternative methods based on semiparametric approaches such as Robinson (1995) and Phillips (2007) which improve the classical log-periodogram estimation method of Geweke and Porter-Hudak (GPH, 1983) produced essentially the same results.

\subsection{Multivariate Results}

The heterogeneity observed in the degrees of integration of the individual series invalidates the analysis based on fractional cointegration, which requires common degrees of differentiation in the series under examination. Thus, 
in what follows, we look at the relationship between the series and consider a regression model as in the one given by equation (2) where $y_{t}$ is GDP PC, and $z_{t}$ is formed by the rest of the variables examined.

The expected signs of the coefficients are presented in Table 3. All independent variables are expected to have a positive relationship with the dependent variable (GDP per capita).

Table 3. Expect signs of the coefficients in equation (2)

\begin{tabular}{cccccccc}
\hline & Oil Export & EPC & Oil Price & Electricity Price & REER & RIR & Employment \\
\hline GDP PC & + & + & + & + & + & - & + \\
\hline
\end{tabular}

GDP PC is GDP per capita; EPC is Electricity Power Consumption; REER means Real Effective Exchange Rate; RIR is Real Interest Rate

Table 4. Results of the multivariate model

\begin{tabular}{clllllll}
\hline $\mathrm{d}$ & OILEXP & EPC & OILPRICE & EPRICE & REER & RIR & EMP \\
\hline $\mathrm{d}=1.31$ & -0.01321 & $\mathbf{0 . 0 9 3 1 5}$ & $\mathbf{0 . 0 8 4 8 9}$ & $\mathbf{0 . 1 1 5 7 9}$ & 0.01374 & $\mathbf{- 0 . 0 0 0 7 3}$ & $\mathbf{2 . 8 2 8 4 9}$ \\
$(-0.09,1.94)$ & $(-0.37)$ & $\mathbf{( 1 . 9 6 )}$ & $\mathbf{( 1 . 9 1 )}$ & $\mathbf{( 2 . 3 3 )}$ & $(0.45)$ & $\mathbf{( - 1 . 9 0 )}$ & $\mathbf{( 2 3 . 2 5 )}$ \\
$\mathrm{d}=0$ & -0.00593 & $\mathbf{0 . 3 1 7 6 5}$ & $\mathbf{0 . 2 5 6 4 1}$ & $\mathbf{0 . 2 9 8 6 1}$ & 0.01294 & $\mathbf{- 0 . 0 0 2 7 3}$ & $\mathbf{2 . 3 3 0 6 4}$ \\
& $(-0.06)$ & $\mathbf{( 4 . 0 4 )}$ & $\mathbf{( 6 . 7 6 )}$ & $\mathbf{( 3 . 3 6 )}$ & $(0.05)$ & $\mathbf{( - 3 . 1 7 )}$ & $\mathbf{( 2 9 . 6 2 )}$ \\
$\mathrm{d}=1$ & -0.0632 & $\mathbf{0 . 1 7 2 9 8}$ & $\mathbf{0 . 1 3 5 4 0}$ & $\mathbf{0 . 2 2 3 9 1}$ & 0.01471 & $\mathbf{- 0 . 0 0 1 3 9}$ & $\mathbf{2 . 6 3 7 1 3}$ \\
& $(-0.19)$ & $\mathbf{( 2 . 0 9 )}$ & $\mathbf{( 2 . 1 4 )}$ & $\mathbf{( 2 . 3 0 )}$ & $(0.45)$ & $\mathbf{( - 1 . 6 6 )}$ & $\mathbf{( 2 1 . 2 2 )}$ \\
& & & & & & & \\
& & & & & & & $\mathbf{( 2 1 . 2 2 )}$ \\
\hline
\end{tabular}

In bold, significant coefficients at the $5 \%$ level.

Table 4 displays the results of the multivariate regression. The second row displays the estimated coefficients when $\mathrm{d}$ is estimated from the data jointly with the remaining parameters. We observe that the value is 1.31 but the interval is so wide $(-0.09,1.94)$ that the two hypotheses of $\mathrm{d}=0$ and $\mathrm{d}=1$ cannot be rejected. This wide confidence interval is clearly a consequence of the small sample size used in this study. The significant coefficients are EPC, OILPRICE, EPRICE, RIR and EMP. It shows that increase in electricity consumption leads to an increase in GDP per capita. Also, an increase in oil price globally increases GDP per capita in Nigeria, resulting from the fact that Nigeria is an oil producing and exporting country; an oil economy. Therefore, GDP per capita depends on oil price. Electricity prices have a positive relation with GDP per capita, this is because electricity is an inelastic (but not perfectly) public good. So, an increase in the price of electricity does not change its demand, and it affects GDP per capita positively because Nigerian population and households keep increasing and businesses are being incorporated daily, thus, the increase in revenue from the energy sector, and inadvertently, increase in GDP per capita. In addition, increased electricity prices also boost electricity supply, which boosts productivity and GDP. Increased electricity prices, which leads to improved supply of electricity, will reduce the amount spent on alternative energy like diesel generators and increase the amount available for businesses to expand or sustain production. Employment has a positive relation with GDP per capita. This agrees with growth theories and models, and the a priori sign. An increase in employment leads to an increase in income and thus, an increase in per capita income. Real interest rate has a negative relationship with GDP per capita due to contractionary monetary policy, which makes the cost of money dearer and may affect productivity of both goods and services as loans become more expensive to service or credit contracted, thus, negatively affecting GDP per capita.

Imposing $\mathrm{d}=0$ and estimating then the remaining parameters, the results are reported in the third row, while the fourth row shows the values of the estimated coefficients with $d=1$. The same significant variables are obtained in the three cases, which is not surprising based on the wide interval observing when estimating the differencing parameter d.

\section{Conclusions}

We have investigated a group of variables related with economic growth and development in Nigeria. These variables include GDP per capita, oil export, electricity consumption, oil price, electricity prices, real interest rate, real effective exchange rate and employment. First, we look at the individual behavior of each series by investigating the orders of integration, and the results dealing with the degree of persistence were very 
heterogeneous across the series. Thus, high levels of persistence were found in the cases of GDP PC and EMPLOYMENT, with orders of integration about 1; for the remaining series, OILEXP, OILPRICE, EPRICE, ERER, and RIR, the unit root hypothesis, i.e., $d=1$, cannot be rejected though for the latter series, the interval is so wide that even the $\mathrm{I}(0)$ hypothesis could not be rejected. Thus, we rule out the hypothesis of mean reversion in the majority of the series examined.

Based on this disparity in the degree of integration across the series, we rule out the possibility of cointegration, and consider a regression model of GDP PC against the rest of the variables, still in an I(d) context. The results here show that electricity power consumption (EPC), oil price (OILPRICE), electricity price (EPRICE), real interest rate (RIR) and employment (EMP) all have a statistically significant relationship with the dependent variable (GDP per capita), with all significant variables except real interest rate having a positive relation with GDP per capita. Oil export surprisingly has a negative relationship with GDP per capita though it is statistically insignificant. Since, three out of the four of the energy variables have a positive statistically significant connection with GDP per capita (an economic development variable), it sufficed to say that the energy sector in Nigeria aids and promises to spearhead economic development in Nigeria.

Based on the results reported in this work, the following policy recommendation should be considered by the Nigerian government. Firstly, Nigeria should increase energy productivity by improving energy efficiency, implementation of energy savings projects, energy conservation, and energy infrastructure outsourcing to achieve its GDP per capita growth. Also, the government should note that petroleum refineries in the country should be repaired, privatized and her capacity increased while taking into consideration, the utilization of carbon capture technologies. This will help increase the production and supply of refined oil and gas products to be exported in the global market while increasing employment opportunities, leading to gains in trade and a concomitant growth in GDP per capita. Furthermore, The Federal government of Nigeria should liaise with the African Development Bank (who launched Light Up and Power Africa- A New Deal Project), the World Bank and IMF to source for macro funds or finance (grants or/and loans) to increase their low investment on energy project to achieve the full energy potential. Lastly, the Central Bank of Nigeria should issue loans for investment by medium, small and micro enterprises (MSMEs) in renewable energy such as wind, solar and biomass energy to increase energy (electricity) supply to match up the demand for energy (electricity), increase energy (electricity) consumption, thus, increasing economic productivity and inadvertently, GDP per capita.

From an econometric perspective, other mathematical modelling approaches can also be examined with these variables. Thus, for example, the possible presence of structural change is an issue that deserves our attention; however, the short sample sizes of the series investigated invalidates this approach. Nevertheless, other methods to investigate this issue include, for example, the non-linear deterministic approach derived in Cuestas and GilAlana (2016) and that is based on the Chebyshev polynomials in time. Alternative methods are the Fourier functions in time examined in Gil-Alana and Yaya (2021) and the neural network approach developed in Yaya et al. (2021). Work in all these directions is now in progress.

\section{Acknowledgments}

Luis A. Gil-Alana gratefully acknowledges financial support from the MINEIC-AEI-FEDER ECO2017-85503-R project from 'Ministerio de Economía, Industria y Competitividad' (MINEIC), `Agencia Estatal de Investigación' (AEI) Spain and 'Fondo Europeo de Desarrollo Regional' (FEDER). An internal Project from the Universidad Francisco de Vitoria is also acknowledged.

\section{References}

Acaravci, A., \& Ozturk, I. (2010). On the relationship between energy consumption, CO2 emissions and economic growth in Europe. Energy, 35(12), 5412-5420. https://doi.org/10.1016/j.energy.2010.07.009

Akinkunmi, M. A. (2017). Nigeria's Economic Growth: Past, Present and Determinants. Journal of Economics and Development Studies 5(2), 31-46. https://doi.org/10.15640/jeds.v5n1a4

Akinlo, A. E. (2008). Energy consumption and economic growth: evidence from 11 Sub- Sahara African countries. Energy Economics, 30(5), 2391-2400. https://doi.org/10.1016/j.eneco.2008.01.008

Akinsola, M. O., \& Odhiambo, N. M. (2020). Asymmetric effect of oil price on economic growth: Panel analysis of low-income oil-importing countries. Energy Reports, 6, 1057-1066. https://doi.org/10.1016/j.egyr.2020.04.023

Alaska (2004). Contaminant Program. Retrieved June 17, 2017, from $\mathrm{http} / / /$ alaska.fws.gov/fisheries/contaminants/index.htm 
Al-mulali, U., \& Che Sab, C. N. B. (2012). The impact of energy consumption and CO2 emission on the economic growth and financial development in the Sub-Saharan African countries. Energy 39, 180-186. https://doi.org/10.1016/j.energy.2012.01.032

Amnesty International (2011). UN Confirms Massive Oil Pollution in Niger Delta. Retrieved June 19, 2017, from http://www.amnestyusa.org/news/news-item/un-confirms-massive-oilpollution-in-niger-delta

Apergis, N., \& Payne, J. E. (2009). Energy consumption and economic growth in Central America: evidence from a panel cointegration and error correction model. Energy Economics, 31(2), 211-216. https://doi.org/10.1016/j.eneco.2008.09.002

Auty, R. (1993). Sustaining development in the mineral economies: the resource curse thesis. London: Routledge.

Awe, O. O., Akinlana, D. M., Yaya, O. S., \& Aromolaran, O. (2018). Time Series Analysis of the Behaviour of Import and Export of Agricultural and Non-Agricultural Goods in West Africa: A Case Study of Nigeria. Agris On-Line Papers in Economics \& Informatics, 10(2), 15-22. https://doi.org/10.22004/ag.econ.276109

Awe, O. O., Crandell, I., Adepoju, A. A., \& Leman, S. (2015). A Time Varying Parameter State-Space Model for Analyzing Money Supply-Economic Growth Nexus. Journal of Statistical and Econometric Methods, 4(1), 73-95. Retrieved from https://EconPapers.repec.org/RePEc:spt:stecon:v:4:y:2015:i:1:f:4_1_4

Awe, O. O., Mudida, R., \& Gil-Alaña, L. A. (2020). Comparative analysis of economic growth in Nigeria and Kenya: A fractional integration approach. International Journal of Finance \& Economics, 26(2), 1197-1205. https://doi.org/10.1002/ijfe.1845

Berndt, E., \& Wood, D. (1975). Technology, Prices and The Derived Demand for Energy. The Review of Economics and Statistics, 57, 259-268. https://doi.org/10.2307/1923910

Bowden, N., \& Payne, J.E. (2010). Sectoral Analysis of the Causal Relationship Between Renewable and NonRenewable Energy Consumption and Real Output in the US. Energy Sources, Part B: Economics, Planning, and Policy, 5(4), 400-408. https://doi.org/10.1080/15567240802534250

Can, M., \& Gozgor, G. (2017). The impact of economic complexity on carbon emissions: evidence from France. Environmental Science Pollution Research, 24, 16364-16370. https://doi.org/10.1007/s11356-017-9219-7

Chen P. F., \& Lee C. C. (2007). Is energy consumption per capita broken stationary? New evidence from regionalbased panels. Energy Policy 35, 3526-40. https://doi.org/10.1016/j.enpol.2006.12.027

Cho, S., Heo, E. \& Kim, J. (2015). Causal relationship between renewable energy consumption and economic growth: comparison between developed and less-developed countries. Geosystem Engineering, 18, 284-291. https://doi.org/10.1080/12269328.2015.1053540

Corina, P., \& Claudiu, C. (2012). Econometric perspective of the energy consumption and economic growth relation in European Union. Renewable and Sustainable Energy Reviews, 16(8), 5718-5726. https://doi.org/10.1016/j.rser.2012.06.010

Cuestas, J. C., \& Gil-Alana, L. A. (2016). A nonlinear approach with long rage dependence based on Chebyshev polynomials in time. Studies in Nonlinear Dynamics and Econometrics, 20, 57-74. https://doi.org/10.1515/snde-2014-0005

Daily Independent (2010). Shell and the N15bn Oil Spill Judgement Debt. The Daily Independent (Lagos). 19 July 2010. Archived

Dong, K., Hochman, G., Zhang, Y., Sun, R., Li, H., \& Liao, H. J. E. E. (2018). CO2 emissions, economic and population growth, and renewable energy: Empirical evidence across regions. Energy Economics, 75, 180192. https://doi.org/10.1016/j.eneco.2018.08.017

Ebohon, O. J. (1996). Energy, economic growth and causality in developing countries. Energy Policy, 24, 447-453. https://doi.org/10.1016/0301-4215(96)0r0027-4

Fallahi F. (2011). Causal relationship between energy consumption (EC) and GDP: a markov-switching (MS) causality. Energy, 36, 4165-70. https://doi.org/10.1016/j.energy.2011.04.027

Geweke, J., \& Porter-Hudak, S. (1983). The estimation and application of long memory time series models. Journal of Time Series Analysis, 4(4), 221-238. https://doi.org/10.1111/j.1467-9892.1983.tb00371.x

Ghali, K. H., \& El-Sakka, M. I. T. (2004). Energy use and output growth in Canada: a multivariate cointegration analysis. Energy Economics, 26(2), 225-238. https://doi.org/10.1016/S0140-9883(03)00056-2

Ghosh, S. (2010). Examining carbon emissions economic growth nexus for India: A multivariate cointegration 
approach. Energy Policy, 38(6), 3008-3014. https://doi.org/10.1016/j.enpol.2010.01.040

Gil-Alana, L. A., \& O. Yaya (2021). Testing fractional unit roots with nonlinear smooth break approximations using Fourier functions. Journal of Applied Statistics, forthcoming. https://doi.org/10.1080/02664763.2020.1757047

Gil-Alana, L. A., Mudida, R., \& Carcel, H. (2017). Shocks Affecting Electricity Prices in Kenya, A Fractional Integration Study. Energy, 124, 521-530. https://doi.org/10.1016/j.energy.2017.02.092

Glasure, Y. U. (2002). Energy and national income in Korea: further evidence on the role of omitted variables. Energy Economics, 24(4), 355-365. https://doi.org/10.1016/S0140-9883(02)00036-1

Griffin, J. M. (1979). Energy Conservation in the OECD: 1980-2000. Ballinger Publishers, Cambridge, MA.

Gylfason, T. (2001). Lessons from the Dutch disease: Causes, treatment, and cures. Institute of Economic Studies Working Paper Series W01:06, 1-25

Hsu Y. C., Lee, C. C., \& Lee C. C. (2008). Revisited: are shocks to energy consumption permanent or temporary? New evidence from a panel SURADF approach. Energy Economics, 30, 2314-30. https://doi.org/10.1016/j.eneco.2007.09.007

Hudson, E. A., \& Jorgenson, D. W. (1974). US energy policy and economic growth, 1975-2000. Bell Journal of Economics and Management Science, 5(2), 461-514. https://doi.org/10.2307/3003118

Kebede, E., Kagochi, J., \& Jolly, C. (2010). Energy consumption and economic development in Sub-Sahara Africa. Energy Economics, 32, 532-7. https://EconPapers.repec.org/RePEc:eee:eneeco:v:32:y:2010:i:3:p:532-537

Lean, H. H., \& Song, Y. (2009). Long memory in US disaggregated petroleum consumption: evidence from univariate and multivariate LM tests for fractional integration. Energy Policy, 37, 3205-3211 https://doi.org/10.1016/j.enpol.2009.04.017

Lee, C., \& Chang C. (2007). The impact of energy consumption on economic growth: evidence from linear and nonlinear models in Taiwan. Energy, 32, 2282-94. https://doi.org/10.1016/j.energy.2006.01.017

Matsui, K. et al. (1978). Economic Activity and Energy on a Stable Growth Course. The Institute of Energy Economics Research Report, 78-2. Tokyo.

Mazur, A., Phutkaradze, Z., \& Phutkaradze, J. (2015). Economic Growth and Environmental Quality in the European Union Countries - Is there Evidence for the Environmental Kuznets Curve? International Journal of Management and Economics, 45(1), 108-126. https://doi.org/10.1515/ijme-2015-0018

Mishra, V., Sharma, S., \& Smyth R. (2009). Are fluctuations in energy consumption per capita transitory? Evidence from a panel of Pacific island countries. Energy Policy, 37, 2318-2326. https://doi.org/10.1016/j.enpol.2009.02.022

Narayan P. K., \& Smyth, R. (2007). Are Shocks to energy consumption permanent or transitory? Evidence from 182 Countries. Energy Policy, 35, 333-341. https://doi.org/10.1016/j.enpol.2005.11.027

National Planning Commission (NPC). (1997). National rolling plan (1997-1999).

NNPC (2013). NNPC Annual Statistical Bulletin. Retrieved August 31, 2020, from https://nnpcgroup.com/PublicRelations/Oil-and-Gas-Statistics/Pages/Annual-Statistics-Bulletin.aspx

Oyedepo, S. (2014). Towards achieving energy for sustainable development in Nigeria. Renewable and Sustainable Energy Reviews, 34, 255-272. https://doi.org/10.1016/j.rser.2014.03.019

Oyedepo, S. (2012). On energy for sustainable development in Nigeria. Renewable and Sustainable Energy Reviews, 16(5), 2583-2598. https://doi.org/10.1016/j.rser.2012.02.010

Payne J. E. (2010). On biomass energy consumption and real output in the US. Energy Sources, Part B: Economics, Planning, and Policy, 6, 47-52. https://doi.org/10.1080/15567240903160906

Radmehr, R., Henneberry, S. R., \& Shayanmehr, S. (2021). Renewable Energy Consumption, CO2 Emissions, and Economic Growth Nexus: A Simultaneity Spatial Modeling Analysis of EU Countries. Structural Change and Economic Dynamics, 57, 13-27. https://doi.org/10.1016/j.strueco.2021.01.006

Rafindadi, A. A., \& Ozturk, I. (2017). Impacts of renewable energy consumption on the German economic growth: Evidence from combined cointegration test. Renewable and Sustainable Energy Reviews, 75, 1130-1141. https://doi.org/10.1016/j.rser.2016.11.093 
Robinson, P. M. (1995), Log-Periodogram Regression of Time Series with Long Range Dependence. Annals of Statistics, 23(3), 1048-1072. https://www.jstor.org/stable/2242436

Robinson, P.M. (1994). Efficient tests of nonstationary hypotheses. Journal of the American Statistical Association, 89, 1420-1437. https://doi.org/10.1080/01621459.1994.10476881

Ross, M. L. (2015). What Have We Learned About the Resource Curse? Annual Review of Political Science, 18, 239-259. https://doi.org/10.1146/annurev-polisci-052213-040359

Saleh, M. A. (2015). Value and Risk Management, [MSc. Research Module] Available at: School of Energy, Geoscience, Infrastructure and Society. Heriot Watt University Edinburgh, United Kingdom. [unpublished]

Saleh, M. A. et al (2017). Risk and Environmental Implications of Oil Spillage in Nigeria (Niger-Delta Region). IIARD International Journal of Geography and Environmental Management 3(2), 44-53. Retrieved from http://iiardpub.org/get/IJGEM/VOL.\%203\%20NO.\%202\%202017/RISK\%20AND\%20ENVIRONMENTA L.pdf

Sambo, A. S. (2009). Strategic developments in renewable energy in Nigeria. International Association of Energy Economics, 15-19.

Soava, G., Mehedintu, A., Sterpu, M., \& Raduteanu, M. (2018). Impact of renewable energy consumption on economic growth: Evidence from European Union countries. Technological and Economic Development of Economy, 24, 914-932. https://doi.org/10.3846/tede.2018.1426

Susuki, K., \& Takenaka, H. (1981). The role of investment for energy conservation: Future Japanese economic growth. Energy Economics 3(4), 233-243. https://doi.org/10.1016/0140-9883(81)90024-4

U.S. Fish \& Wildlife Service (2017). WILD. Retrieved June 17, 2017, from http://www.fws.gov

UNDP (2013). Niger Delta Human Development Report. p. 76. Perfect Printers Ltd, Lagos

Venables, A. J. (2016). Using Natural Resources for Development: Why Has it Proven so Difficult? Journal of Economic Perspectives, 30(1), 161-184. https://doi.org/10.1257/jep.30.1.161

Vidal, J. (2010). Nigeria's agony dwarfs the Gulf oil spill. The US and Europe ignore it. The Observer. Retrieved August 31, 2020, from https:/www.theguardian.com/world/2010/may/30/oil-spills-nigeria-niger-delta-shell

Warr, B. S., \& Ayres, R. U. (2010). Evidence of causality between the quantity and quality of energy consumption and economic growth. Energy, 35, 1688-93. https://doi.org/10.1016/j.energy.2009.12.017

Wesseh, P. K., \& Lin, B. (2018). Energy consumption, fuel substitution, technical change, and economic growth: Implications for $\mathrm{CO} 2$ mitigation in Egypt. Energy Policy, 117, 340-347. https://doi.org/10.1016/j.enpol.2018.03.022

World Bank (1993). Issues and Options in the Energy Sector, Report No. 11672-UNI. Nigeria: World Bank.

World Bank (2014). Doing Business 2015: Going Beyond Efficiency. Washington, DC: World Bank Group. https://doi.org/10.1596/978-1-4648-0351-2

World Bank (2019). The World Bank in Nigeria. Retrieved August 31, 2020, from https://www.worldbank.org/en/country/nigeria/overview

Yaya, O., Ogbonna, A. E., Furuoka, F., \& Gil-Alana, L. A. (2021). A New Unit Root Test for Unemployment Hysteresis Based on the Autoregressive Neural Network, Oxford Bulletin of Economics and Statistics, forthcoming. https://doi.org/10.1111/obes.12422

Yoo, S. (2006). Oil consumption and economic growth: evidence from Korea. Energy Sources, Part B: Economics, Planning, and Policy, 1, 235-243. https://doi.org/10.1080/009083190881599

You, J. (2011). China's energy consumption and sustainable development: comparative evidence from GDP and genuine savings. Renewable and Sustainable Energy Reviews, 15, 2984-2989. https://doi.org/10.1016/j.rser.2011.03.026

\section{Copyrights}

Copyright for this article is retained by the author(s), with first publication rights granted to the journal.

This is an open-access article distributed under the terms and conditions of the Creative Commons Attribution license (http://creativecommons.org/licenses/by/4.0/). 